\title{
KARAKTERISASI EDIBLE FILM DARI PATI PROPAGUL MANGROVE LINDUR (Bruguiera gymnorrhiza) DENGAN PENAMBAHAN CARBOXYMETHYL CELLULOSE (CMC) SEBAGAI PEMLASTIS
}

\author{
CHARACTERIZATION OF EDIBLE FILM FROM PROPAGULES MANGROVE LINDUR \\ (Bruguiera gymnorrhiza) STARCH WITH ADDITION OF CARBOXYMETHYL CELLULOSE \\ (CMC) AS PLASTICIZER
}

\author{
Azka Prima Nurindra, Moch. Amin Alamsjah dan Sudarno \\ Fakultas Perikanan dan Kelautan Universitas Airlangga \\ Kampus C Mulyorejo - Surabaya, 60115 Telp. 031-5911451
}

\begin{abstract}
The using of synthetic packaging generally has a problem for healthy and nature. This plastic rubbish can't degredable by nature and soil. Necessary alternative packaging technology which safe and degredable that is edible film. Use of single material in edible film as starch have some shortage, that is brittle and rigid. Therefore, it is necessary to add material as plasticizer. Plasticizer that use in this study is Carboxymethyl Cellulose. This purpose of this study is to know the effect addition of carboxymethyl cellulose on characterization edible film from propagules mangorve B.gymnorrhiza. The method of this study is experimental with Completely Randomized Design. The treatment is concentration addition of $\mathrm{CMC}$, that is A $(0 \%), \mathrm{B}(0,2 \%), \mathrm{C}(0,4 \%), \mathrm{D}(0,6 \%), \mathrm{E}(0,8 \%), \mathrm{F}(1 \%)$ and $\mathrm{G}(1,2 \%)$, with four repeatations. Parameters measured were thcikness, water vapor transmission rate, tensile strength and elongation at break. Data analysis using Analysis of Varioan (ANOVA) and if there is difference significant on the result, further with Duncan's Multiple Range Test. The result of this study show that addition of CMC have different very significant $(\mathrm{p}<0,01)$ on thickness, water vapor transmission rate, tensile strength and elongation at break. The best treatment in this study is treatment G (addition CMC concentration 1,2\%) with scoring method which basicaly on JIS (Japanesse Industrial Standard)
\end{abstract}

Keywords : Bruguiera gymnorrhiza, characteristic of edible film, carboxymethyl cellulose

\section{Pendahuluan}

Bertambahnya jumlah penduduk menyebabkan kebutuhan pangan meningkat dan masyarakat semakin memahami akan pentingnya kualitas pangan, yaitu dengan meningkatnya kesadaran penggunaan kemasan yang mudah terdegradasi dan aman bagi kesehatan (Utari, 2012).

Penggunaan kemasan sintetis yang umum digunakan selama ini menimbulkan masalah bagi kesehatan dan lingkungan hidup. Sekitar $30-40 \%$ sampah di daerah perkotaan diperkirakan terdiri dari sampah plastik (Suminto, 2006). Oleh karena itu diperlukan suatu teknologi kemasan yang aman dan tidak merusak lingkungan, salah satunya dengan penggunaan edible film (Fannema, 1994 dalam Utari, 2012).

Edible film didefinisikan sebagai lapisan tipis yang dapat dimakan yang ditempatkan di atas atau diantara komponen makanan, dapat memberikan alternatif bahan pengemas yang tidak berdampak pada pencemaran lingkungan karena menggunakan bahan yang dapat diperbaharui (Bourtoom, 2007).

Pati sering digunakan dalam industri pangan sebagai biodegradable film untuk menggantikan polimer plastik karena ekonomis, dapat diperbaharui dan memberikan karakteristik fisik yang baik. Pati yang termasuk ke dalam polisakarida dapat digunakan sebagai bahan baku pembuatan edible film (Bourtoom, 2007).

Hasil penelitian Institut Pertanian Bogor bekerja sama dengan badan BIMAS Ketahanan Pangan Nusa Tenggara Timur, menyatakan bahwa kandungan karbohidrat propagul lindur 85,1 gram per 100 gram, lebih tinggi dari kandungan karbohidrat beras 78,9 gram per 100 gram dan jagung 63,3 per 100 gram (Fortuna, 2005). Penggunaan bahan tunggal pada edible film seperti pati masih menyisakan beberapa kekurangan diantaranya adalah sifat rapuh dan tidak elastis, oleh karena itu perlu ditambahkan bahan tambahan yaitu 
pemlastis (Khotimah dkk., 2006). Salah satu bahan pemlastis yang dapat digunakan adalah karboksimetil selulosa (CMC).

Penelitian ini bertujuan untuk mengetahui pengaruh konsentrasi pemlastis carboxymethyl cellulose (CMC) berbeda terhadap ketebalan, kuat tarik, perpanjangan putus dan laju transmisi uap air edible film dari pati propagul Bruguiera gymnorrhiza. Adapun manfaat dari penelitian ini adalah dapat memberikan informasi tentang pengaruh konsentrasi pemlastis carboxymethyl cellulose (CMC) berbeda terhadap ketebalan, kuat tarik, perpanjangan putus dan laju transmisi uap air edible film dari pati propagul Bruguiera gymnorrhiza.

\section{Materi dan Metode}

Tempat dan Waktu

Kegiatan penelitian ini dilakukan di laboratorium kering Fakultas Perikanan dan Kelautan Universitas Airlangga, pada bulan Januari 2015. Uji karakterisasi edible film dilakukan di laboratorium pangan dan gizi Fakultas Teknologi Industri Pertanian Universitas Gadjah Mada, pada bulan Februari 2015.

\section{Alat dan Bahan}

Bahan baku utama yang digunakan dalam penelitian ini adalah propagul Bruguiera gymnorrhiza yang diperoleh dari Greges, Kecamatan Asemrowo, Surabaya. Bahan tambahan yang digunakan dalam pembuatan edible film adalah natrium metabisulfit $\left(\mathrm{Na}_{2} \mathrm{~S}_{2} \mathrm{O}_{3}\right)$, carboxymethyl cellulose (CMC), aquades. Bahan yang digunakan untuk pengujian karakteristik edible film adalah silika gel.

Alat yang digunakan untuk ekstraksi pati adalah blender, timbangan analitik, kain mori. Alat yang digunakan untuk pembuatan edible film adalah beaker glass, gelas ukur, magnetic stirer, hot plate stirer, termometer, spatula, selotip, mortar, plat kaca, oven dan alat untuk analisis karakteristik fisik dari edible film yaitu universal testing machine, mikrometer dan moisture cup water vapor transmission rate.

\section{Metode Penelitian \\ Penelitian ini terdiri dari dua tahap, yaitu tahap pembuatan tepung propagul $B$. Gymnorrhiza dan tahap penelitian utama. Penelitian utama terdiri dari pembuatan dan uji karakterisasi edible film.}

Pembuatan Tepung Pati Propagul Lindur (Bruguiera gymnorrhiza)
Tahapan pembuatan tepung pati propagul lindur adalah propagul yang telah dikupas kulitnya dan dibersihkan kemudian dipotong kecil-kecil. Propagul B.gymnorrhiza (lindur) selanjutnya dihaluskan menggunakan blender yang sebelumnya ditimbang dan ditambah natrium metabisulfit sebanyak $0,25 \%$ $(\mathrm{b} / \mathrm{v})$ serta air 1:4 (b/v). Natrium metabisulfit digunakan untuk mempertahankan derajat putih tepung pati propagul B.gymnorrhiza (lindur).

$$
\text { Adanya penambahan natrium }
$$
metabisulfit $\left(\mathrm{Na}_{2} \mathrm{~S}_{2} \mathrm{O}_{3}\right)$ dapat mencegah timbulnya warna coklat akibat reaksi enzimatik. Bubur propagul lindur yang dihasilkan kemudian disaring dengan kain sehingga terpisah antara pati dan ampas. Susu pati yang diperoleh diendapkan selama enam jam pada suhu ruang. Air hasil pengendapan dibuang, kemudian pati yang didapat dikeringkan pada suhu $50^{\circ} \mathrm{C}$ selama \pm 12 jam. Pati yang telah kering kemudian dihaluskan dan diayak dengan saringan 150 mesh hingga diperoleh serbuk pati yang halus (Modifikasi dari Utari, 2012)

\section{Pembuatan Edible Film}

Edible film yang dibuat pada penelitian ini menggunakan pati propagul lindur, carboxymethyl cellulose (CMC) dan akuades. Perlakuan yang diberikan pada penelitian ini adalah pati propagul lindur sebanyak satu gram (4\% dari total larutan edible film $25 \mathrm{ml}$ ), dengan konsentrasi penambahan CMC sebanyak $0 \%$, $0,2 \%, 0,4 \%, 0,6 \%, 0,8 \%, 1 \%$ dan $1,2 \%$ dari total larutan edible film $25 \mathrm{ml}$. Tahapan pembuatan edible film dilakukan dengan modifikasi metode Utari (2012).

Tepung pati propagul lindur yang telah dibuat sebelumnya dilarutkan dalam $25 \mathrm{ml}$ akuades sambil diaduk dengan magnetic stirrer dan dipanaskan di atas hot plate stirrer pada suhu $80^{\circ} \mathrm{C}$ selama 10 menit. CMC ditambahkan sesuai formulasi ke dalam larutan tersebut, diaduk dan dipanaskan kembali selama lima menit. Larutan edible film dihasilkan kemudian dituangkan pada plat kaca ukuran 15 x $20 \mathrm{~cm}$ dan diratakan untuk menghindari perbedaan keteblan. Film pada plat kaca dikeringkan pada suhu ruang selama dua hari, edible film yang telah kering kemudian dilepas dari cetakan.

\section{Karakterisasi Edible Film}

Pengujian yang dilakukan terhadap edible film yang dihasilkan meliputi ketebalan, kuat tarik, perpanjangan putus, dan laju transmisi uap air edible film. Hasil dari karakteristik edible film tersebut dibandingkan dengan JIS (Japanesse Industrial Standart) 
untuk dapat dikategorikan sebagai plastik film untuk kemasan makanan.

\section{Analisa Data}

Data yang diperoleh terlebih dahulu ditabulasi ke dalam bentuk tabel dan grafik dan dianalisis secara statistik dengan analisa varian (anava). Apabila analisis ragam menunjukkan pengaruh nyata $(\mathrm{p}<0,05)$ terhadap respon pengamatan, maka dilakukan uji jarak berganda Duncan untuk mengetahui perbedaan antara perlakuan satu dengan perlakuan lainnya.

\section{Hasil dan Pembahasan}

Ketebalan

Hasil pengujian ketebalan edible film dari pati Bruguiera gymnorrhiza (lindur) pada masing-masing perlakuan A $(0 \%), \mathrm{B}(0,2 \%), \mathrm{C}$ $(0,4 \%), \mathrm{D}(0,6 \%), \mathrm{E}(0,8 \%), \mathrm{F}(1 \%)$ dan $\mathrm{G}$ $(1,2 \%)$ yaitu $0,0798 \mathrm{~mm}, 0,0846 \mathrm{~mm}, 0,0856$ $\mathrm{mm}, 0,0862 \mathrm{~mm}, 0,0896 \mathrm{~mm}, 0,0946 \mathrm{~mm}$ dan $0,0987 \mathrm{~mm}$. Hasil analisis sidik ragam menunjukkan penambahan konsentrasi CMC berbeda sangat nyata $(\mathrm{p}<0,01)$ terhadap nilai ketebalan.

Nilai ketebalan tertinggi terdapat pada perlakuan $\mathrm{G}$ (penambahan CMC sebanyak $1,2 \%$ ) yaitu $0,0987 \mathrm{~mm}$, sedangkan nilai ketebalan terendah terdapat pada perlakuan A (tanpa penambahan CMC) yaitu 0,0798 mm. Seiring bertambahnya konsentrasi CMC, nilai ketebalan edible film mengalami peningkatan

Laju transmisi uap air

Hasil pengujian laju transmisi uap air edible film dari pati Bruguiera gymnorrhiza (lindur) pada masing-masing perlakuan A $(0 \%)$, B $(0,2 \%), \mathrm{C}(0,4 \%), \mathrm{D}(0,6 \%), \mathrm{E}(0,8 \%), \mathrm{F}$ (1\%) dan $\mathrm{G}(1,2 \%)$ yaitu $22,8832 \mathrm{~g} / \mathrm{m}^{2} /$ hari, $21,4169 \mathrm{~g} / \mathrm{m}^{2} /$ hari, $21,1948 \mathrm{~g} / \mathrm{m}^{2} /$ hari, 20,0938 $\mathrm{g} / \mathrm{m}^{2} /$ hari, $19,7564 \mathrm{~g} / \mathrm{m}^{2} /$ hari, $18,8975 \mathrm{~g} / \mathrm{m}^{2} /$ hari dan $15,7156 \mathrm{~g} / \mathrm{m}^{2} /$ hari. Penambahan konsentrasi CMC berbeda sangat nyata $(\mathrm{p}<0,01)$ terhadap nilai laju transmisi uap air.

Nilai laju transmisi uap air tertinggi terdapat pada perlakuan A (tanpa penambahan

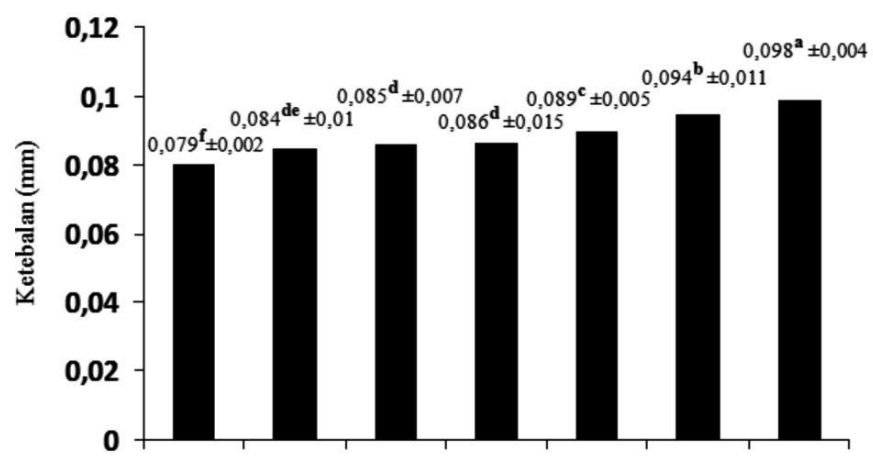

$\begin{array}{lllllll}\text { (A) } 0 & \text { (B) } 0,2 & \text { (C) } 0,4 & \text { (D) } 0,6 & \text { (E) } 0,8 & \text { (F) } 1 & \text { (G) } 1,2\end{array}$

Konsentrasi Penambahan CMC (\%)

Gambar 1. Grafik ketebalan edible film pati propagul B.gymnorrhiza $4 \%$ dengan penambahan konsentrasi pemlastis CMC berbeda

Keterangan : angka-angka yang diikuti huruf superskrip berbeda (a,b) menunjukkan berbeda nyata $(\mathbf{p}<0,05)$ pada faktor konsentrasi CMC

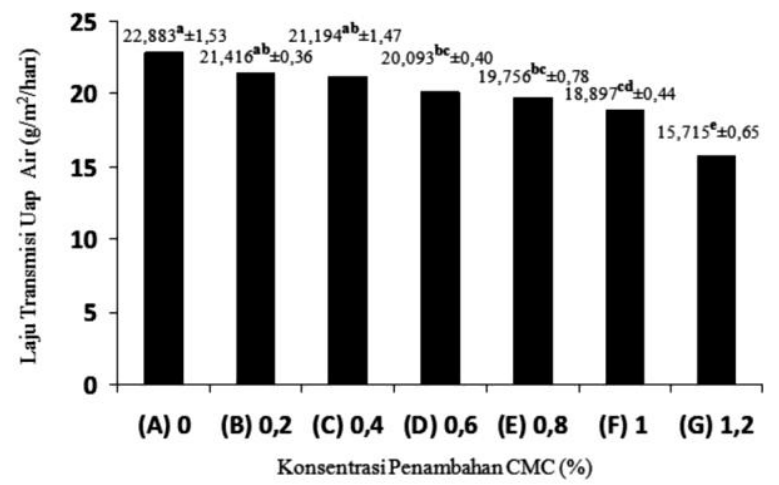

Gambar 2. Grafik laju transmisi uap air edible film pati propagul B.gymnorrhiza $4 \%$ dengan penambahan konsentrasi pemlastis CMC berbeda

Keterangan : angka-angka yang diikuti huruf superskrip berbeda $(\mathrm{a}, \mathrm{b})$ menunjukkan berbeda nyata $(p<0,05)$ pada faktor konsentrasi CMC 
CMC) yaitu $22,8832 \mathrm{~g} / \mathrm{m}^{2} /$ hari, sedangkan nilai laju transmisi uap air terendah terdapat pada perlakuan G (penambahan CMC sebanyak $1,2 \%$ ) yaitu $15,7156 \mathrm{~g} / \mathrm{m}^{2} /$ hari.

Kuat tarik

Hasil pengujian kuat tarik edible film dari pati Bruguiera gymnorrhiza (lindur) pada masing-masing perlakuan A $(0 \%), \mathrm{B}(0,2 \%), \mathrm{C}$ $(0,4 \%), \mathrm{D}(0,6 \%), \mathrm{E}(0,8 \%), \mathrm{F}(1 \%)$ dan $\mathrm{G}$ $(1,2 \%)$ yaitu 9,2169 $\mathrm{MPa}, 4,0039 \mathrm{MPa}, 3,5899$ $\mathrm{MPa}, 1,9656 \mathrm{MPa}, 1,7008 \mathrm{MPa}, 1,5785 \mathrm{MPa}$ dan 1,5294 MPa. Hasil analisis sidik ragam menunjukkan penambahan konsentrasi CMC berbeda sangat nyata $(\mathrm{p}<0,01)$ terhadap nilai kuat tarik edible film.

Kuat tarik tertinggi terdapat pada perlakuan A (tanpa penambahan CMC) yaitu 9,2169 $\mathrm{MPa}$, sedangkan nilai kuat tarik terendah terdapat pada perlakuan $\mathrm{G}$ (penambahan CMC sebanyak 1,2\%) yaitu 1,5294 MPa. Seiring bertambahnya konsentrasi CMC, nilai kuat tarik edible film mengalami penurunan.
Perpanjangan putus

Hasil pengujian perpanjangan putus edible film dari pati Bruguiera gymnorrhiza (lindur) pada masing-masing perlakuan A $(0 \%)$, B $(0,2 \%), C(0,4 \%), D(0,6 \%)$, E $(0,8 \%), F$ $(1 \%)$ dan $\mathrm{G}(1,2 \%)$ yaitu $1,0209 \%, 3,0952 \%$, $6,7372 \%, 7,051 \%, 7,5806 \%, 9,1543 \%$ dan $12,9614 \%$. Hasil analisis sidik ragam menunjukkan penambahan konsentrasi CMC berbeda sangat nyata $(\mathrm{p}<0,01)$ terhadap nilai perpanjangan putus edible film.

Nilai perpanjangan putus tertinggi terdapat pada perlakuan $\mathrm{G}$ (penambahan CMC $1,2 \%$ ) yaitu $12,9614 \%$, sedangkan nilai perpanjangan putus terendah terdapat pada perlakuan A (tanpa penambahan CMC) yaitu $1,0209 \%$.

Penentuan perlakuan terbaik

Kriteria yang menjadi penilaian penting dalam pemilihan konsentrasi CMC terbaik adalah nilai ketebalan, laju transmisi uap

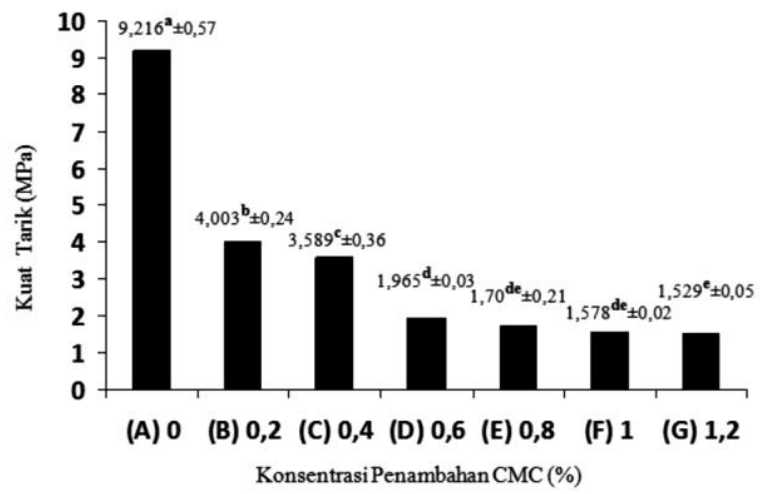

Gambar 3. Grafik kuat tarik edible film pati propagul B.gymnorrhiza $4 \%$ dengan

\begin{tabular}{ll}
\multirow{2}{*}{ Keterangan } & penambahan konsentrasi pemlastis CMC berbeda \\
: angka-angka yang diikuti huruf superskrip berbeda (a,b) menunjukkan
\end{tabular} berbeda nyata $(p<0,05)$ pada faktor konsentrasi CMC

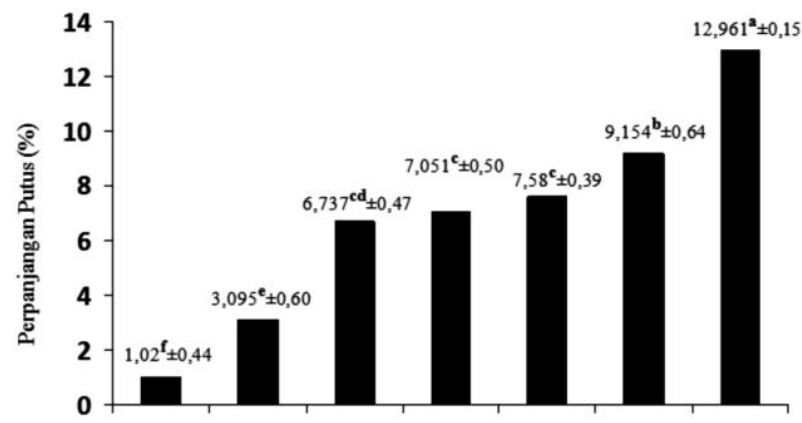

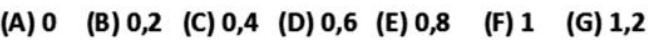

KonsentrasiPenambahan CMC (\%)

Gambar 4.Grafik perpanjangan putus edible film pati propagul B.gymnorrhiza $4 \%$ dengan penambahan konsentrasi pemlastis CMC berbeda Keterangan $\quad$ angka-angka yang diikuti huruf superskrip berbeda $(\mathrm{a}, \mathrm{b})$ menunjukkan
berbeda nyata $(\mathrm{p}<0,05)$ pada faktor konsentrasi CMC. 
Tabel 1. Hasil scoring dan ranking edible film oleh panelis

\begin{tabular}{|c|c|c|c|c|c|c|c|}
\hline \multirow{2}{*}{ Parameter } & \multicolumn{7}{|c|}{ Konsentrasi CMC } \\
\cline { 2 - 8 } & $\begin{array}{c}\mathrm{A} \\
(0 \%)\end{array}$ & $\begin{array}{c}\mathrm{B} \\
(0,2 \%)\end{array}$ & $\begin{array}{c}\mathrm{C} \\
(0,4 \%)\end{array}$ & $\begin{array}{c}\mathrm{D} \\
(0,6 \%)\end{array}$ & $\begin{array}{c}\mathrm{E} \\
(0,8 \%)\end{array}$ & $\begin{array}{c}\mathrm{F} \\
(1 \%)\end{array}$ & $\begin{array}{c}\mathrm{G} \\
(1,2 \%)\end{array}$ \\
\hline Ketebalan (mm) & 1 & 2 & 3 & 4 & 5 & 6 & 7 \\
\hline $\begin{array}{c}\text { Laju transmisi uap air } \\
\left(\mathrm{g} / \mathrm{m}^{2} / \text { hari) }\right.\end{array}$ & 1 & 2 & 3 & 4 & 5 & 6 & 7 \\
\hline Kuat tarik (MPa) & 7 & 6 & 5 & 4 & 3 & 2 & 1 \\
\hline Perpanjangan putus (\%) & 1 & 2 & 3 & 4 & 5 & 6 & 7 \\
\hline Total nilai & 10 & 12 & 14 & 16 & 18 & 20 & 22 \\
\hline Ranking & 7 & 6 & 5 & 4 & 3 & 2 & 1 \\
\hline
\end{tabular}

air, kuat tarik dan perpanjangan putus. Penentuan perlakuan terbaik didapatkan dengan cara scoring oleh panelis yang kemudian diberi ranking dari masing-masing perlakuan edible film.

Nilai ketebalan, laju transmisi uap air, kuat tarik dan perpanjangan putus edible film yang mendekati kriteria JIS (Japanesse Industrial Standart) akan diberi score paling tinggi, dan sebaliknya apabila jauh dari kriteria JIS (Japanesse Industrial Standart) maka akan diberi score paling rendah. Score dari masingmasing perlakuan dijumlahkan dan diberi ranking untuk mendapatkan perlakuan terbaik.

Ketebalan edible film merupakan parameter penting yang berpengaruh terhadap penggunaan film dalam pembentukan produk yanng akan dikemas. Seiring dengan penambahan konsentrasi $\mathrm{CMC}$ nilai rata-rata ketebalan edible film mengalami peningkatan (Gambar 6). Hasil analisis sidik ragam menunjukkan bahwa perlakuan penambahan konsentrasi CMC memberikan pengaruh sangat nyata $(\mathrm{p}<0,01)$ terhadap nilai ketebalan.

Hasil uji lanjut dengan uji jarak berganda Duncan memperlihatkan adanya perbedaan yang nyata antara edible film dari pati tanpa penambahan CMC dengan edible film yang ditambahkan CMC. Edible film pada perlakuan A (tanpa penambahan CMC) memiliki nilai ketebalan yang lebih rendah dibandingkan edible film yang ditambahkan CMC. Hal ini disebabkan karena semakin banyak total padatan yang terdapat dalam larutan maka semakin tebal pula film (Handayani, 2010).

Dalam cetakan yang sama, film yang terbentuk akan lebih tebal apabila volume larutan yang dituangkan ke dalam cetakan lebih banyak. Nilai ketebalan edible film akan berpengaruh terhadap nilai laju transmisi uap air (Suryaningrum et al., 2005).

Berpedoman pada JIS (Japanesse Industrial Standart), plastik film untuk kemasan makanan yang dikategorikan film adalah yang mempunyai ketebalan maksimal 0,25 mm. Edible film dari pati B.gymnorrhiza dalam penelitian ini masih memenuhi standar untuk dikategorikan sebagai film kemasan makanan, karena ketebalan film yang dihasilkan berkisar antara 0,0798-0,0987 mm. Dari hasil nilai ketebalan edible film dapat ditentukan perlakuan terbaik yaitu pada perlakuan G (Penambahan $1,2 \%$ CMC) yang memiliki nilai ketebalan mendekati kriteria JIS dengan nilai 0,0987 mm.

Laju transmisi uap air terdiri dari proses pelarutan dan difusi aktif dimana uap air larut pada salah satu sisi film dan kemudian berdifusi melewati sisi lain. Kecepatan ketahanan terhadap laju transmisi uap air ditentukan dalam kondisi ketebalan, suhu, tekanan gradien parsial uap air (McHugh dan Krochta, 1994).

Nilai laju transmisi uap air mengalami penurunan seiring dengan penambahan konsentrasi CMC (Gambar 7). Parameter ini berbanding terbalik dengan nilai ketebalan, apabila nilai ketebalan meningkat maka nilai laju transmisi uap air akan menurun. Semakin tebal film yang dihasilkan, maka semakin sedikit peluang uap air yang masuk pada sisi film. Hasil analisis sidik ragam menunjukkan bahwa perlakuan penambahan konsentrasi CMC memberikan pengaruh sangat nyata $(p<0,01)$ terhadap nilai laju transmisi uap air. 
Berbasis pada JIS (Japanesse Industrial Standart), plastik film untuk kemasan makanan yang dikategorikan film adalah yang mempunyai laju transmisi uap air maksimal 7 $\mathrm{g} / \mathrm{m}^{2} /$ hari. Laju transmisi uap air dari hasil penelitian ini belum memenuhi standar film kemasan, karena nilai laju transmisi uap air yang diperoleh melebihi standar yaitu antara $15,7156-22,8832 \mathrm{~g} / \mathrm{m}^{2} /$ hari.

Nilai laju transmisi uap air yang tinggi akan berdampak pada lama penyimpanan produk yang akan dikemas. Semakin tinggi nilai laju transmisi uap air edible film yang digunakan, maka semakin tidak awet produk yang dikemas.

Tingginya laju transmisi uap air pada penelitian ini disebabkan karena film terbuat dari pati dan CMC yang merupakan polisakarida. McHugh dan Krochta (1994) menyatakan bahwa umumnya film yang terbuat dari bahan protein dan polisakarida mempunyai nilai transmisi uap air yang tinggi.

Polisakarida merupakan polimer polar dan mempunyai jumlah ikatan hidrogen yang besar, sehingga menghasilkan penyerapan air pada kelembaban tinggi. Penyerapan air akan mengganggu interaksi rantai molekuler yang kemudian diikuti dengan peningkatan difusi dan mampu menyerap uap air dari udara.

Dari hasil nilai laju transmisi uap air edible film dapat ditentukan perlakuan terbaik yaitu pada perlakuan $\mathrm{G}$ (penambahan 1,2\% CMC) dimana nilai laju transmisi uap air mendekati kriteria JIS dengan nilai 15,7156 $\mathrm{g} / \mathrm{m}^{2} /$ hari.

Kuat tarik menunjukkan nilai maksimum gaya yang diproduksi jika dilakukan uji tarik. Edible film dengan kekuatan tarik yang tinggi akan mampu melindungi produk yang dikemasnya dari gangguan mekanis dengan baik. Nilai kuat tarik mengalami penurunan seiring dengan penambahan konsentrasi CMC (Gambar 8). Hal ini menunjukkan bahwa struktur molekul edible film adalah amorf.

Pada struktur molekul amorf, rantairantai bercabang namun tidak tersusun secara rapat sehingga jarak antar molekul menjadi lebih jauh dan kekuatan ikatan molekul menjadi melemah. Lemahnya kekuatan ikatan molekul dalam edible film menyebabkan semakin rendahnya gaya yang dibutuhkan untuk memutuskan edible film tersebut (Delvia, 2006). Analisis sidik ragam menunjukkan bahwa penambahan CMC berpengaruh sangat nyata $(\mathrm{p}<0,01)$ terhadap nilai kuat tarik edible film.

Nilai kuat tarik edible film yang berkisar antara 1,5294-9,2169 $\mathrm{MPa}$ dapat dikategorikan sebagai film kemasan makanan, karena nilai kuat tarik edible film pada JIS (Japanesse Industrial Standart) minimal 0,392266 MPa. Berdasarkan hasil nilai kuat tarik edible film dapat ditentukan perlakuan terbaik yaitu pada perlakuan A (tanpa penambahan CMC) dimana nilai kuat tarik lebih tinggi dari nilai perlakuan yang lain dengan nilai 9,2169 $\mathrm{MPa}$.

Perpanjangan putus merupakan persen pertambahan panjang bahan materi film yang diukur mulai dari panjang awal pada saat mengalami penarikan hingga putus. Nilai perpanjangan putus mengalami peningkatan seiring dengan penambahan konsentrasi CMC (Gambar 9).

Parameter ini berbanding terbalik dengan nilai kuat tarik. Apabila semakin kecil nilai kuat tarik, maka nilai perpanjangan putus akan semakin besar. Hasil analisis sidik ragam menunjukkan bahwa penambahan CMC berpengaruh sangat nyata $(\mathrm{p}<0,01)$ terhadap nilai perpanjangan putus.

CMC memiliki gel strenght yang tinggi. Penggunaan CMC dalam jumlah yang lebih besar menyebabkan kemampuan mengikat air yang lebih baik sehingga memberikan matriks gel yang dapat meningkatkan persen pemanjangan dari edible film. Semakin besar nilai persen pemanjangannya, maka semakin baik edible film karena lebih elastis dan tidak mudah sobek (Yulianti dan Erliana, 2012).

Plastik film untuk kemasan makanan yang dikategorikan film adalah yang mempunyai nilai minimal 70\% (Japanesse Industrial Standart). Nilai perpanjangan putus pada penelitian ini yang berkisar antara 1,0209$12,9614 \%$ masih belum memenuhi standar untuk dikategorikan film kemasan makanan.

Berdasarkan hasil nilai perpanjangan putus edible film dapat ditentukan perlakuan terbaik yaitu pada perlakuan $\mathrm{G}$ (penambahan $1,2 \% \mathrm{CMC}$ ) dimana nilai perpanjangan putus lebih tinggi dari nilai perlakuan yang lain dengan nilai $12,9614 \%$.

Dari hasil penentuan perlakuan terbaik edible film diperoleh hasil bahwa penambahan CMC sebanyak 1,2\% (perlakuan G) merupakan perlakuan terbaik diantara perlakuan yang lain. Metode yang digunakan dengan cara scoring karena setiap parameter edible film memiliki standar yang berbeda-beda sesuai dengan JIS (Japanesse Industrial Standart).

Penambahan konsentrasi CMC sebanyak 1,2\% (perlakuan G) diberi score paling tinggi pada parameter ketebalan, laju transmisi uap air dan perpanjangan putus edible film, namun pada parameter kuat tarik diberi 
score paling rendah karena memiliki nilai paling kecil.

Nilai kuat tarik tertinggi pada perlakuan A (tanpa penambahan CMC), namun pada perlakuan A hanya memiliki nilai yang baik dari segi kuat tarik saja sehingga total score pada perlakuan A masih selisish jauh dari total score perlakuan $\mathrm{G}$ yang memiliki nilai score tertinggi pada parameter ketebalan, perpanjangan putus dan laju transmisi uap air. Total score yang diperoleh dari proses scoring selanjutnya diberi ranking.

Urutan pemberian ranking edible film mulai dari ranking satu hingga tujuh yaitu penambahan konsentrasi CMC sebanyak 1,2\% (perlakuan G), $01 \%$ (perlakuan F), $0,8 \%$ (perlakuan E), $0,6 \%$ (perlakuan D), $0,4 \%$ (Perlakuan C), 0,2\% (perlakuan B) dan $0 \%$ (perlakuan A). Dari hasil ranking tersebut, maka dapat ditentukan bahwa perlakuan dengan penambahan CMC sebanyak $1,2 \%$ (perlakuan $\mathrm{G})$ adalah perlakuan terbaik karena diberi ranking pertama.

Kelebihan dari perlakuan $\mathrm{G}$ yaitu dapat memberikan nilai parameter yang baik pada ketebalan, laju transmisi uap air dan perpanjangan putus yang berpedoman pada JIS (Japanesse Industrial Standart), sehingga penggunaan konsentrasi 1,2\% CMC lebih efisien dalam pembuatan edible film. Kelemahan dari perlakuan $G$ adalah memiliki nilai kuat tarik yang rendah, sehingga hanya dapat digunakan sebagai edible film untuk materi (bahan makanan) yang ringan.

\section{Kesimpulan}

Penambahan pemlastis carboxymethyl cellulose (CMC) dengan konsentrasi berbeda berpengaruh sangat nyata $(p<0,01)$ terhadap ketebalan, kuat tarik, perpanjangan putus dan laju transmisi uap air edible film dari pati propagul Bruguiera gymnorrhiza. Penambahan konsentrasi CMC meningkatkan nilai ketebalan dan perpanjangan putus, namun menurunkan nilai laju transmisi uap air dan kuat tarik.

Hasil perlakuan terbaik yaitu pada perlakuan $G$ dengan penambahan CMC sebanyak $1,2 \%$, yang diperoleh dengan cara scoring berpedoman pada JIS (Japanesse Industrial Standart). perlakuan G memiliki nilai ketebalan 0,0987 mm, laju transmisi uap air $15,7156 \mathrm{~g} / \mathrm{m}^{2} /$ hari, kuat tarik 1,5294 MPa dan perpanjangan putus $12,9614 \%$.

\section{Daftar Pustaka}

Ahmed, J., S.H. Imam, M.A. Rao and B.K Tiwari. 2012. Starch Based Polymeric Materials and Nanocomposites:
Chemistry, Processing and Applications. CRC Press: Taylor and Francis Group. New York. Pp. 1, 2, 242, 326.

American Society for Testing and Material. 1989. Standard Method For Oxygen Gas Transmission Rate of Material. Philadelphia: ATM Book of Standards D385-81.

Bonilla, J., L. Atares, A. Chiralt. 2012. Edible Films and Coatings to Prevent the Detrimental Effect Oxygen on Food Quality: Possibilities and Limitations. Journal of Food Engineering 110:208213.

Bourtoom, T. 2007. Efect of Some Process Parameters on the Porperties of Edible Film Prepared from Strach. Songkhla: Departement of Material Product Technology. Challenges and Opportunities. Food Technology 51(2): 61-73.

Cui, S. W. 2005. Food Carbohidrates Chemistry, Physical Properties, and Aplications. Boca Raton, FL: CRC Press, Taylor \& Francis Group.

Delvia, V. 2006. Kajian Pengaruh Penambahan Dietilen Glikol Sebagai Pemlastis pada Karakteristik Bioplastik dari Poli-B-Hidroksialkanoat (PHA) yang Dihasilkan Ralstonia eutropha pada Substrat Hidrolisat Pati Sagu.

Duke, N.C. and James A.A. 2006. Bruguiera gymnorrhiza Species Profiles for Pacific Island Agroforestry Apr; Version 2. I.

Handayani, A. 2010. Pembuatan dan Karakterisasi Film Biodegredable dari Kitosan/PLA (Polu Lactid Acid) dengan Pemlastis Polietilen Glikol (PEG). Skripsi. Fakultas Teknologi Pertanian. Institut Pertanian Bogor.

Harsunu, B. 2008. Pengaruh Konsentrasi Plasticizer Gliserol dan Komposisi Khitosan dalam Zat Pelarut Terhadap Sifat Fisik Edible Film dari Khitosan. Skripsi. Departemen Metalurgi dan Material. Fakultas Teknik. Universitas Indonesia.

Herliany, E.N. 2011. Aplikasi Kappa Karagenan dari Rumput Laut Kappaphycus alvarezii sebagai Edible Coating pada Udang Kupas Rebus. Tesis. Bogor: Program Pascasarjana, Institut Pertanian Bogor.

Huri, D. dan Fithri C. N. 2014. Pengaruh Konsentrasi Gliserol dan Ekstrak Ampas Kulit Apel Terhadap 
Karakterisasi Edible Film dari.....

Karakteristik Fisik dan Kimia Edible

Film. Jurnal Pangan dan Agroindustri Vol. 2 No. 4.

JIS(Japanesse Industrial Standard) 21707.

1975. Japanese Standards Association.

J 